\title{
Effects of Whole-Body Vibration in Hematobiochemical and Hemogasometric Parameters in Adult and Elderly Healthy Dogs
}

\author{
Bruna Martins da Silva', Ivan Felismino Charas dos Santos' ${ }^{1}$ Sheila Canevese Rahal', Carmel Dadalto ${ }^{1}$, \\ Lais Rosa Nagai', Miriam Tsunemi², Francisco José Teixeira Neto' \& Maria Jaqueline Mamprim'
}

\begin{abstract}
Background: Whole-Body Vibration (WBV) consists of mechanical vibration stimuli produced that propagate throughout the body by increasing the gravitational load. The WBV can increase muscle mass in dogs with muscular atrophy. As Whole-body vibration (WBV) can be used as exercise modality with no impact on the joints, the present study aimed to evaluate the effects of single session of WBV in hematobiochemical and hemogasometric parameters in adult and elderly healthy dogs.

Materials, Methods \& Results: Fourteen clinically healthy, neutered crossbreed male dogs, non-athlete were selected. The dogs were divided into two groups of seven dogs, according to the age group: Group I - adult dogs (GI): age between 12.0 and 84.0 months old; Group II - elderly dogs (GII): age above 84.0 months old. All dogs were submitted to a single session WBV by using a vibrating platform that delivered a vortex wave circulation as mechanical vibration. The WBV protocol used was $30 \mathrm{~Hz}$ frequency $\left(3.10 \mathrm{~mm}\right.$ peak displacement; $11.16 \mathrm{~m} / \mathrm{s}^{2}$ peak acceleration; $0.29 \mathrm{~m} / \mathrm{s}$ velocity), then $50 \mathrm{~Hz}\left(3.98 \mathrm{~mm}\right.$ peak displacement; $39.75 \mathrm{~m} / \mathrm{s}^{2}$ peak acceleration; $0.62 \mathrm{~m} / \mathrm{s}$ velocity), and lastly $30 \mathrm{~Hz}(3.10 \mathrm{~mm}$ peak displacement; $11.16 \mathrm{~m} / \mathrm{s}^{2}$ peak acceleration; $0.29 \mathrm{~m} / \mathrm{s}$ velocity) for 5 -min between de frequencies. The hematobiochemical and hemagasometric parameters were evaluated at 1-min before the WBV session (1PRE), 1-min after the WBV session (1POST), 120-min (120POST) and $24 \mathrm{~h}$ after the WBV session (24hPOST). The dogs accepted the vibration stimulus quite well, however, elderly dogs weighing above $30 \mathrm{~kg}$ were more likely to sit down with increased frequency from 30 to $50 \mathrm{~Hz}$. No variations of food and water intakes and gastrointestinal changes were observed after the WBV session. Hemoglobin values showed significant decrease $(P=0.0312)$ between 1PRE and 1POST in elderly dogs. A significant decrease $(P=0.0453)$ was observed in alanine aminotransferase values between 120POST and 14hPOST in adult dogs. Creatinine values had a statistical decrease $(P=0.0173)$ between 1PRE and 24hPOST in adult dogs. However, these values remained within the reference range for dogs.

Discussion: According to the literature, there are no studies related to the effects of WBV in haematobiochemical and hemogasometric parameters in adult and elderly dogs. No deleterious effects regarding a single session of WBV were observed, however harmful effects were observed in human patients. The elderly dogs with body mass above $30 \mathrm{~kg}$ tried to sit during the increased frequency from 30 to $50 \mathrm{~Hz}$, which was associated with the pressure exerted in their paws. No significant differences were observed in erythrogram and leukogram parameters except for hemoglobin values. Significant decline was observed in hemoglobin values in adult Beagle dogs; and were associated with hemolysis. The significant decrease in alanine aminotransferase and creatinine values did not have clinical significance. No significant alterations were identified in hemogasometric parameters but slight increase in $\mathrm{pH}$ values was observed in horses subjected to a 60 $\mathrm{km}$ run, and was associated with the loss of $\mathrm{Cl}$ ions in sweat. The single session of WBV by using a vibrating platform that delivered a vortex wave circulation, at 30 and $50 \mathrm{~Hz}$ frequencies for $5 \mathrm{~min}$ did not induce significant changes in hematobiochemical and hemogasometric parameters in adults and elderly healthy dogs.
\end{abstract}

Keywords: alternative therapy, blood, rehabilitation, vibration, vortex wave.

DOI: $10.22456 / 1679-9216.105418$ Accepted: 27 November 2020

Published: 31 December 2020 


\section{INTRODUCTION}

Whole-Body Vibration (WBV) consists of mechanical vibration stimuli produced by vibrating platforms that propagate throughout the body by increasing the gravitational load, and activate the neuromuscular, cardiovascular, and musculoskeletal systems [3,22]. In human patients, WBV has been used as an alternative modality of rehabilitation and physical training with results associated with increased muscle strength and regional blood flow, higher bone mineral density, and neuromuscular stimulation [3,9,17,19,20,24,29]. Increased muscle contractions and blood flow associated with an increment in muscle mass is highly beneficial in dogs with postoperative muscular atrophy of different conditions, such as cruciate ligament rupture; patellar luxation, scapulohumeral and hip luxation, osteoarthritis, among others [6,28].

In Veterinary Medicine there are few studies related to WBV in dogs [11,25-27], and the clinical significance of the present study was related if the WBV may induce negative effects in laboratory parameters in adult and elderly healthy dogs since WBV can be used as an alternative rehabilitation modality in dogs with muscle atrophy.

As WBV can be used as rehabilitation and exercise modality without impact on the joints, the study aimed the effects of single session of WBV in hematobiochemical and hemogasometric parameters in adult and elderly healthy dogs by using a vibrating platform that delivered a vortex wave circulation. We hypothesized that a single session of WBV $(30 \mathrm{~Hz}$ and $50 \mathrm{~Hz}$, for $5 \mathrm{~min}$ ) in these groups of dogs do not induce deleterious effects in hematobiochemical and hemogasometric parameters.

\section{MATERIALS AND METHODS}

\section{Experimental environment and animals' selection}

Dogs' owners were used, and they were informed of all study procedures, and an authorization form was signed. The study was carried out in GPS: Latitude: -22.888941850000002; Longitude: -48.49840491716181 .

Fourteen clinically healthy, neutered crossbreed male dogs, non-athlete were selected. Inclusion criteria were the absence of changes during the clinical exam and musculoskeletal neurological con- ditions examination; absence of changes in complete blood count and serum biochemistry values (alanine aminotransferase - ALT, aspartate aminotransferase - AST, creatinine - CREAT, creatine kinase - CK, total serum protein - TSP, albumin - ALB, serum glucose - SG); absence of cardiac structural changes by echocardiographic examination; dogs with body condition score (BCS) of three in the 9-point body condition scoring [16]; and dogs with body proportion smaller than 1 (dogs with a long body or short limbs) [30].

Dogs that had undergone a surgical procedure and received medication at least six months before the study and dogs that presented mitral endocarditis with hemodynamic repercussions in left cardiac chambers and presented arterial hypertension were excluded. All dogs were considered sociable and docile, and they stayed most of the time indoors and went for a 20 min daily walk on the leash. Their diet consisted of 250 to $300 \mathrm{~g}$ per day of dry food for medium size dogs.

\section{Experimental design}

The dogs were randomly allocated into two groups of seven dogs, according to the age group: Group I - adult dogs (GI): age between 12.0 and 84.0 months old; Group II - elderly dogs (GII): age above 84.0 months old. Each dog fasted from food for $6 \mathrm{~h}$, and water was withheld $4 \mathrm{~h}$ before the WBV session. The animals were subjected to physical rest and acclimatization $1 \mathrm{~h}$ before the sessions on top of the vibrating platform, but disconnected. The sessions were performed in the room with constant $22^{\circ} \mathrm{C}$ and humidity between 40 to $45 \%$. Noise and more than two persons in the room were avoided.

\section{Whole-body vibration}

All dogs were submitted to a single session WBV by using the vibrating platform that delivered a vortex wave circulation (TheraPlate $\left.{ }^{\circledR}\right)^{1}$ with the following dimensions: $92 \mathrm{~cm}$ length, $62 \mathrm{~cm}$ width and $16 \mathrm{~cm}$ height. The protocol used was $30 \mathrm{~Hz}$ frequency, then $50 \mathrm{~Hz}$ (3.98 mm peak displacement; $39.75 \mathrm{~m} / \mathrm{s}^{2}$ peak acceleration; $0.62 \mathrm{~m} / \mathrm{s}$ velocity), and lastly $30 \mathrm{~Hz}(3.10 \mathrm{~mm}$ peak displacement; 11.16 $\mathrm{m} / \mathrm{s}^{2}$ peak acceleration; $0.29 \mathrm{~m} / \mathrm{s}$ velocity). The peak displacement, peak acceleration and velocity at $30 \mathrm{~Hz}$ was $3.10 \mathrm{~mm}, 11.16 \mathrm{~m} / \mathrm{s}^{2}$ and $0.29 \mathrm{~m} / \mathrm{s}$, respectively; and at $50 \mathrm{~Hz}$ was $3.98 \mathrm{~mm}$ of peak 
displacement, $39.75 \mathrm{~m} / \mathrm{s}^{2}$ of peak acceleration, and a velocity of $0.62 \mathrm{~m} / \mathrm{s}$. The exposure time for each frequency was 5-min without rest between the frequency's variation.

According to the manufacturer, the vibration frequencies can be chosen between 05 and 100 Hz. A digital oscilloscope was used to check the vibration frequencies, and an accelerometer device was used to measure the peak acceleration (Apeak). The peak displacement (Dpeak) and velocity (V) was calculated using DPeak $=\operatorname{Apeak} /(2 . f)^{2}, \mathrm{f}-$ vibration frequency; and $\mathrm{V}=$ Dpeak. $\pi . f(\pi=3.14)$, respectively $[6,21]$.

The hematobiochemical and hemagasometric parameters were evaluated at $1 \mathrm{~min}$ before the WBV session (1PRE), 1 min after the WBV session (1POST), $120 \mathrm{~min}$ (120POST) and $24 \mathrm{~h}$ after the WBV session (24hPOST).

\section{Haematobiochemical parameters}

Five milliliters $(5 \mathrm{~mL})$ and $2 \mathrm{~mL}$ of blood samples was used for hematological and biochemical analysis, respectively. All blood samples were collected with a 21-gauge needle (Needles $\left.\mathrm{BD}^{\circledR}\right)^{2}$ on a $10 \mathrm{~mL}$ syringe $\left(\text { Syringe } \text { Lock }^{\circledR}\right)^{3}$ with the dogs standing on the vibrating platform, but disconnected. The blood samples for haematology analysis were immediately placed in $5 \mathrm{~mL}$ plastic tubes (BD Vacutainer Plus Tubes with heparin $\left.{ }^{\circledR}\right)^{2}$ containing lithium heparin, and the ones for serum biochemistry analysis were immediately placed in $5 \mathrm{~mL}$ plastic tube (BD Vacutainer Tubes with plasma separator $\left.{ }^{\circledR}\right)^{2}$ without anticoagulant, and containing plasma separator, and the tubes were promptly centrifuged. Red blood cell values were determined by an electronic cell counter, whereas the white blood cell values were verified by using a Wright-stained blood smear and examined under an optical microscope at X100.

The serum biochemistry (ALT, AST, CK, and SG) values were determined by using a biochemistry commercial kit $\left(\text { Labtest }^{\circledR}\right)^{4}$. The CREAT values were performed by applying a colorimetric method $\left(\text { Spectronic } 21^{\circledR}\right)^{5}$. Total serum protein and ALB were determined by utilizing the biuret method and a biochemistry commercial kit (Labtest $\left.{ }^{\circledR}\right)^{4}$, and the values were read with an automated spectrophotometer $\left(\text { Cobas-Mira }{ }^{\circledR}\right)^{6}$.

\section{Hemagasometric parameters}

Blood samples (1 mL) were obtained from the jugular vein with continuous flow through a heparinized insulin syringe with a 21-gauge needle (Needles $\left.\mathrm{BD}^{\circledR}\right)^{2}$. The results of $\mathrm{pH}$, partial pressure of oxygen $(\mathrm{PaO} 2)$, partial pressure of carbon dioxide $(\mathrm{PaCO} 2)$, sodium $(\mathrm{Na})$, potassium $(\mathrm{K})$, chlorine $(\mathrm{Cl})$, and bicarbonate (HCO3-) results were determined by using a RapidLab test $\left(\text { Siemens }^{\circledR}\right)^{7}$. All exams were performed by our pathology clinical laboratory, and by the same person using a blinded method.

\section{Statistical analyses}

All results were expressed as mean \pm standard deviation. Data normality at each time point and group was analysed through the Shapiro-Wilk Test. The comparison between time points for each group was performed using the mixed model analysis considering the time points as a random effect and using the MannWhitney Test. The computer statistics R (Version 3.4.4) 8 was used for statistical analyses, being $P$-values less than 0.05 considered statistically significant.

\section{RESULTS}

Of a total of 21 dogs evaluated, 14 met the inclusion criteria that were assigned to two groups. Group I (GI) ( $\mathrm{n}=7)$ - adult dogs: aged $27.40 \pm 5.90$ months old, and body weight of $22.81 \pm 3.40 \mathrm{~kg}$; and Group II (GII) ( $\mathrm{n}=7)$ - elderly dogs: aged $96.00 \pm$ 13.90 months old, and $27.82 \pm 8.80 \mathrm{~kg}$ of body weight.

The dogs accepted the vibration stimulus quite well, and $92.9 \%$ of them remained standing on the vibrating platform throughout the WBV session. However, elderly dogs weighing above $30 \mathrm{~kg}$ were more likely to sit down with increased frequency from 30 to $50 \mathrm{~Hz}$. All dogs remained calm after the WBV session. No variations of food and water intakes and gastrointestinal changes (diarrhea and vomiting) were observed after the WBV session.

There were no significant differences in erythrogram and leukogram parameters in adult and elderly dogs at all time-points, except for the hemoglobin values that showed a significant $(P=0.0312)$ decrease between 1PRE and 1POST in elderly dogs (Table 1). Adult dogs showed significant decline in ALT values $(P=0.0453)$ between 120POST and 24hPOST, and in CREAT values between 1PRE and 24hPOST (Table 2).

There were no significant differences in hemogasometric parameters between groups and time points (Table 3 ). 
B.M. Silva, I.F.C. Santos, S.C. Rahal, et al. 2020. Effects of Whole-Body Vibration in Hematobiochemical and Hemogasometric Parameters in Adult and Elderly Healthy Dogs.

Acta Scientiae Veterinariae. 48: 1777.

Table 1. Mean and standard deviation (Mean \pm SD) of hemogram parameters at 1PRE, 1POST, 120POST and 24hPOST in GI and GII.

\begin{tabular}{|c|c|c|c|c|}
\hline Parameter & $1 \mathrm{PRE}$ & 1POST & $120 \mathrm{POST}$ & $24 \mathrm{hPOST}$ \\
\hline \multicolumn{5}{|c|}{ Erythrocytes $\left(\times 10^{6} / \mu\right)$} \\
\hline GI $(n=7)$ & $7.2 \pm 0.7^{\mathrm{Aa}}$ & $6.4 \pm 0.5^{\mathrm{Aa}}$ & $6.4 \pm 0.7^{\mathrm{Aa}}$ & $6.8 \pm 0.6^{\mathrm{Aa}}$ \\
\hline GII $(n=7)$ & $7.4 \pm 0.6^{\mathrm{Aa}}$ & $6.5 \pm 0.8^{\mathrm{Aa}}$ & $6.6 \pm 0.7^{\mathrm{Aa}}$ & $6.9 \pm 0.9^{\mathrm{Aa}}$ \\
\hline \multicolumn{5}{|c|}{ Hemoglobin(g/dL) } \\
\hline GI $(n=7)$ & $16.2 \pm 1.9^{\mathrm{Aa}}$ & $14.9 \pm 1.7^{\mathrm{Aa}}$ & $14.4 \pm 1.9^{\mathrm{Aa}}$ & $15.5 \pm 1.7^{\text {Aa }}$ \\
\hline GII $(n=7)$ & $16.8 \pm 1.3^{\mathrm{Aa}}$ & $14.8 \pm 1.5^{\mathrm{BCa}}$ & $15.1 \pm 1.4^{\mathrm{ABa}}$ & $15.8 \pm 1.8^{\mathrm{ABa}}$ \\
\hline \multicolumn{5}{|c|}{ Packed cell volume (\%) } \\
\hline GI $(n=7)$ & $48.0 \pm 5.3^{\mathrm{Aa}}$ & $44.6 \pm 4.6^{\mathrm{Aa}}$ & $43.8 \pm 5.5^{\mathrm{Aa}}$ & $45.0 \pm 4.3^{\mathrm{Aa}}$ \\
\hline GII $(n=7)$ & $49.3 \pm 5.7^{\mathrm{Aa}}$ & $44.6 \pm 4.6^{\mathrm{Aa}}$ & $46.0 \pm 4.8^{\mathrm{Aa}}$ & $47.6 \pm 5.1^{\mathrm{Aa}}$ \\
\hline \multicolumn{5}{|l|}{ Platelets $(/ \mu \mathrm{L})$} \\
\hline GI $(n=7)$ & $264.0 \pm 78.0^{\mathrm{Aa}}$ & $248.0 \pm 79.0^{\mathrm{Aa}}$ & $231.0 \pm 91.0^{\mathrm{Aa}}$ & $263.0 \pm 85.0^{\mathrm{Aa}}$ \\
\hline GII $(n=7)$ & $233.0 \pm 88.0^{\mathrm{Aa}}$ & $245.0 \pm 19.0^{\mathrm{Aa}}$ & $260.0 \pm 79.0^{\mathrm{Aa}}$ & $251.0 \pm 10.0^{\mathrm{Aa}}$ \\
\hline \multicolumn{5}{|c|}{ Leukocytes $\left(\times 10^{3} / \mu \mathrm{L}\right)$} \\
\hline GI $(n=7)$ & $11.2 \pm 2.6^{\mathrm{Aa}}$ & $11.3 \pm 1.2^{\mathrm{Aa}}$ & $12.7 \pm 2.4^{\mathrm{Aa}}$ & $13.6 \pm 5.5^{\mathrm{Aa}}$ \\
\hline $\operatorname{GII}(\mathrm{n}=7)$ & $8.9 \pm 3.3^{\mathrm{Aa}}$ & $8.7 \pm 1.9^{\mathrm{Aa}}$ & $9.1 \pm 4.7^{\mathrm{Aa}}$ & $9.20 \pm 2.10^{\mathrm{Aa}}$ \\
\hline \multicolumn{5}{|c|}{ Neutrophils $\left(\mathrm{x} 10^{3} / \mu \mathrm{L}\right)$} \\
\hline GI $(n=7)$ & $7.1 \pm 1.2^{\mathrm{Aa}}$ & $8.1 \pm 1.5^{\mathrm{Aa}}$ & $8.6 \pm 2.5^{\mathrm{Aa}}$ & $10.1 \pm 4.8^{\mathrm{Aa}}$ \\
\hline GII $(n=7)$ & $6.0 \pm 1.7^{\mathrm{Aa}}$ & $6.3 \pm 2.2^{\mathrm{Aa}}$ & $6.7 \pm 1.7^{\mathrm{Aa}}$ & $6.6 \pm 1.7^{\mathrm{Aa}}$ \\
\hline \multicolumn{5}{|c|}{ Eosinophils $\left(\times 10^{3} / \mu \mathrm{L}\right)$} \\
\hline GI $(n=7)$ & $1.0 \pm 0.3^{\mathrm{Aa}}$ & $1.1 \pm 0.4^{\mathrm{Aa}}$ & $1.20 \pm 0.6^{\mathrm{Aa}}$ & $0.7 \pm 0.4^{\mathrm{Aa}}$ \\
\hline GII $(n=7)$ & $0.8 \pm 0.6^{\mathrm{Aa}}$ & $0.6 \pm 0.4^{\mathrm{Aa}}$ & $0.50 \pm 0.3^{\mathrm{Aa}}$ & $0.8 \pm 0.8^{\mathrm{Aa}}$ \\
\hline \multicolumn{5}{|c|}{ Lymphocytes $\left(\mathrm{x} 10^{3} / \mu \mathrm{L}\right)$} \\
\hline GI $(n=7)$ & $2.5 \pm 1.6^{\mathrm{Aa}}$ & $1.7 \pm 1.0^{\mathrm{Aa}}$ & $2.2 \pm 1.5^{\mathrm{Aa}}$ & $2.0 \pm 1.0^{\mathrm{Aa}}$ \\
\hline GII $(n=7)$ & $1.9 \pm 1.7^{\mathrm{Aa}}$ & $1.3 \pm 0.5^{\mathrm{Aa}}$ & $1.5 \pm 1.0^{\mathrm{Aa}}$ & $1.4 \pm 0.8^{\mathrm{Aa}}$ \\
\hline \multicolumn{5}{|c|}{ Monocytes $\left(\mathrm{x} 10^{3} / \mu \mathrm{L}\right)$} \\
\hline GI $(n=7)$ & $0.5 \pm 0.3^{\mathrm{Aa}}$ & $0.5 \pm 0.2^{\mathrm{Aa}}$ & $0.7 \pm 0.3^{\mathrm{Aa}}$ & $0.7 \pm 0.5^{\mathrm{Aa}}$ \\
\hline GII $(n=7)$ & $0.2 \pm 0.8^{\mathrm{Aa}}$ & $0.4 \pm 0.4^{\mathrm{Aa}}$ & $0.3 \pm 0.2^{\mathrm{Aa}}$ & $0.4 \pm 0.3^{\mathrm{Aa}}$ \\
\hline
\end{tabular}

Means followed by different capital letters on the same line were significantly different by the mixed model test $(P<0.05)$ Means followed by different lower-case letters in the same column were significantly different by the Mann-Whitney test $(P<0.05)$.

Table 2. Mean and standard deviation (Mean \pm SD) of biochemistry parameters at 1PRE, 1POST, 120POST and 24hPOST in GI and GII.

\begin{tabular}{|c|c|c|c|c|}
\hline Parameter & 1PRE & 1POST & 120POST & 24hPOST \\
\hline \multicolumn{5}{|l|}{ ALT (UI/L) } \\
\hline GI $(n=7)$ & $37.4 \pm 8.6^{\mathrm{ABa}}$ & $37.3 \pm 5.7^{\mathrm{ABa}}$ & $33.7 \pm 11.3^{\mathrm{Ba}}$ & $45.3 \pm 9.4^{\mathrm{Aa}}$ \\
\hline GII $(n=7)$ & $63.8 \pm 34.7^{\mathrm{Aa}}$ & $59.1 \pm 35.9^{\mathrm{Aa}}$ & $56.4 \pm 38.2^{\mathrm{Aa}}$ & $64.1 \pm 36.5^{\mathrm{Aa}}$ \\
\hline \multicolumn{5}{|l|}{ AST (UI/L) } \\
\hline GI $(n=7)$ & $39.7 \pm 2.9^{\mathrm{Aa}}$ & $37.7 \pm 5.9^{\mathrm{Aa}}$ & $38.0 \pm 3.8^{\mathrm{Aa}}$ & $44.3 \pm 13.4^{\mathrm{Aa}}$ \\
\hline GII $(n=7)$ & $33.3 \pm 5.2^{\mathrm{A}}$ & $36.6 \pm 8.0^{\mathrm{Aa}}$ & $31.4 \pm 7.0^{\mathrm{Aa}}$ & $36.4 \pm 7.5^{\mathrm{Aa}}$ \\
\hline \multicolumn{5}{|l|}{ CK (UI/L) } \\
\hline GI $(n=7)$ & $234.4 \pm 250.8^{\mathrm{Aa}}$ & $214.4 \pm 214.7^{\mathrm{Aa}}$ & $230.0 \pm 224.2^{\mathrm{Aa}}$ & $250.8 \pm 462.0^{\mathrm{Aa}}$ \\
\hline GII $(n=7)$ & $112.6 \pm 88.8^{\mathrm{Aa}}$ & $151.1 \pm 116.7^{\text {Aa }}$ & $146.8 \pm 107.8^{\mathrm{Aa}}$ & $126.7 \pm 38.5^{\mathrm{Aa}}$ \\
\hline \multicolumn{5}{|c|}{ CREAT (mg/dL) } \\
\hline GI $(n=7)$ & $1.1 \pm 0.2^{\mathrm{Aa}}$ & $1.1 \pm 0.2^{\mathrm{ABa}}$ & $1.0 \pm 0.2^{\mathrm{Aba}}$ & $0.8 \pm 0.2^{\mathrm{Ba}}$ \\
\hline GII $(n=7)$ & $1.2 \pm 0.2^{\mathrm{Aa}}$ & $1.1 \pm 0.2^{\mathrm{Aa}}$ & $1.1 \pm 0.2^{\mathrm{Aa}}$ & $1.0 \pm 0.4^{\mathrm{Aa}}$ \\
\hline \multicolumn{5}{|l|}{$\mathrm{TSP}(\mathrm{g} / \mathrm{dL})$} \\
\hline GI $(n=7)$ & 7. $\pm 0.9^{\mathrm{Aa}}$ & $7.0 \pm 0.9^{\mathrm{Aa}}$ & $7.4 \pm 1.0^{\mathrm{Aa}}$ & $7.6 \pm 0.7^{\mathrm{Aa}}$ \\
\hline GII $(n=7)$ & $5.60 \pm 0.8^{\mathrm{Aa}}$ & $7.7 \pm 0.8^{\mathrm{Aa}}$ & $7.8 \pm 0.6^{\mathrm{Aa}}$ & $8.4 \pm 0.7^{\mathrm{Aa}}$ \\
\hline \multicolumn{5}{|l|}{ ALB (g/dL) } \\
\hline GI $(\mathrm{n}=7)$ & $3.4 \pm 0.6^{\mathrm{Aa}}$ & $3.4 \pm 0.5^{\mathrm{Aa}}$ & $3.4 \pm 0.6^{\mathrm{Aa}}$ & $3.4 \pm 0.6^{\mathrm{Aa}}$ \\
\hline GII $(n=7)$ & $3.7 \pm 0.4^{\mathrm{Aa}}$ & $3.5 \pm 0.4^{\mathrm{Aa}}$ & $3.5 \pm 0.3^{\mathrm{Aa}}$ & $3.6 \pm 0.5^{\mathrm{Aa}}$ \\
\hline \multicolumn{5}{|l|}{$\mathrm{SG}(\mathrm{mg} / \mathrm{dL})$} \\
\hline GI $(n=7)$ & $101.6 \pm 33.6^{\mathrm{Aa}}$ & $95.3 \pm 23.6^{\mathrm{Aa}}$ & $99.8 \pm 16.6^{\mathrm{Aa}}$ & $93.1 \pm 26.7^{\mathrm{Aa}}$ \\
\hline GII $(n=7)$ & $101.8 \pm 14.5^{\mathrm{Aa}}$ & $104.0 \pm 30.7^{\mathrm{Aa}}$ & $104.1 \pm 17.2^{\mathrm{Aa}}$ & $108.7 \pm 12.4^{\mathrm{Aa}}$ \\
\hline
\end{tabular}

Means followed by different capital letters on the same line were significantly different by the mixed model test $(P<0.05)$ Means followed by different lower-case letters in the same column were significantly different by the Mann-Whitney test $(P<0.05)$. 
B.M. Silva, I.F.C. Santos, S.C. Rahal, et al. 2020. Effects of Whole-Body Vibration in Hematobiochemical and Hemogasometric

Table 3. Mean and standard deviation (Mean \pm SD) of hemagasometric parameters at 1PRE, 1POST, 120POST and 24hPOST in GI and GII.

\begin{tabular}{|c|c|c|c|c|}
\hline Parameter & 1PRE & 1POST & 120POST & $24 \mathrm{hPOST}$ \\
\hline \multicolumn{5}{|l|}{$\mathrm{pH}$} \\
\hline $\mathrm{GI}(\mathrm{n}=7)$ & $7.40 \pm 0.10$ & $7.40 \pm 0.10$ & $7.40 \pm 0.10$ & $7.40 \pm 0.10$ \\
\hline GII $(n=7)$ & $7.40 \pm 0.10$ & $7.40 \pm 0.02$ & $7.50 \pm 0.10$ & $7.40 \pm 0.10$ \\
\hline \multicolumn{5}{|l|}{$\mathrm{PaO}_{2}(\mathrm{mmHg})$} \\
\hline GI $(n=7)$ & $44.10 \pm 9.400$ & $36.70 \pm 6.80$ & $45.80 \pm 13.30$ & $55.50 \pm 12.30$ \\
\hline GII $(\mathrm{n}=7)$ & $37.60 \pm 10.0$ & $41.60 \pm 4.30$ & $38.40 \pm 8.10$ & $45.30 \pm 4.90$ \\
\hline \multicolumn{5}{|c|}{$\mathrm{PaCO}_{2}(\mathrm{mmHg})$} \\
\hline GI (n=7) & $33.60 \pm 7.50$ & $38.10 \pm 3.30$ & $37.50 \pm 4.80$ & $31.90 \pm 5.30$ \\
\hline GII $(n=7)$ & $34.00 \pm 5.60$ & $34.50 \pm 2.10$ & $36.30 \pm 5.60$ & $31.60 \pm 3.50$ \\
\hline \multicolumn{5}{|l|}{$\mathrm{Na}(\mathrm{mEq} / \mathrm{L})$} \\
\hline GI $(n=7)$ & $156.70 \pm 2.80$ & $156.70 \pm 2.40$ & $156.00 \pm 4.60$ & $156.70 \pm 4.60$ \\
\hline GII (n=7) & $150.30 \pm 5.20$ & $155.3 \pm 2.00$ & $155.70 \pm 3.60$ & $150.0 \pm 7.00$ \\
\hline \multicolumn{5}{|l|}{$\mathrm{K}(\mathrm{mEq} / \mathrm{L})$} \\
\hline GI $(n=7)$ & $4.00 \pm 0.90$ & $3.90 \pm 1.00$ & $3.60 \pm 0.80$ & $3.70 \pm 1.10$ \\
\hline GII $(\mathrm{n}=7)$ & $3.70 \pm 1.60$ & $3.70 \pm 1.10$ & $3.20 \pm 0.30$ & $3.50 \pm 1.00$ \\
\hline \multicolumn{5}{|l|}{$\mathrm{Cl}(\mathrm{mmol} / \mathrm{L})$} \\
\hline GI $(\mathrm{n}=7)$ & $114.00 \pm 6.90$ & $115.40 \pm 4.20$ & $115.30 \pm 6.70$ & $115.70 \pm 2.40$ \\
\hline GII $(\mathrm{n}=7)$ & $113.10 \pm 6.30$ & $116.00 \pm 6.30$ & $117.30 \pm 1.70$ & $116.10 \pm 5.70$ \\
\hline \multicolumn{5}{|c|}{$\mathrm{HCO}_{3-}-(\mathrm{mmo} / \mathrm{L})$} \\
\hline $\mathrm{GI}(\mathrm{n}=7)$ & $21.35 \pm 2.2$ & $22.30 \pm 2.00$ & $22.70 \pm 2.80$ & $20.50 \pm 2.30$ \\
\hline GII $(n=7)$ & $20.80 \pm 1.8$ & $21.30 \pm 2.10$ & $21.70 \pm 1.50$ & $20.40 \pm 1.90$ \\
\hline
\end{tabular}

\section{DISCUSSION}

The aim of the present study was to evaluate the acute effects of WBV in hematobiochemical and hemogasometric parameters in adult and elderly healthy dogs since WBV can be used as exercise modality for increase of muscle mass with no impact on the joints. On the other hand, there are no studies related to the effects of WBV in haematobiochemical and hemogasometric parameters in dogs.

The authors established that a single session of WBV with frequencies of 30 and $50 \mathrm{~Hz}$, for $5 \mathrm{~min}$, cannot induce deleterious effects in haematobiochemical and hemogasometric parameters in adult and elderly healthy dogs since the values that showed significant differences remained within the reference range.

Studies regarding WBV have described in animals [4,5,11-13,25-27], and the present study focused on the acute effects of WBV as an exercise modality in dogs with muscular atrophy since the mechanical vibration produce muscle contractions and a greater regional blood supply and, consequently, an increase in muscle mass [3,22,27].

No deleterious effects regarding a single session of WBV were observed, however harmful effects were observed in human patients $[10,14,18]$.
The vibrating platform used in the study was designed for dogs and cats and did not allow modifications that could influence the results. The standing position of the dogs at the vibrating platform during the WBV session was meant to ensure a uniform distribution of the vibrating stimulus throughout their body $[2,6,20,22,30]$.

The WBV protocol used in the present study was the same as the literature [11, 25-27] since it was proved to be safe in dogs. The elderly dogs with body mass above $30 \mathrm{~kg}$ tried to sit during the increased frequency from 30 to $50 \mathrm{~Hz}$, which was associated with the pressure exerted in their paws [7,8]. Study performed in healthy adult horses submitted to a single session of WBV identified absence of any type of discomfort in healthy horses [4].

No significant differences were observed in erythrogram and leukogram parameters except for hemoglobin values. Such values revealed a significant $(\mathrm{P}=0.0312)$ reduction between 1PRE and 1POST in elderly dogs, but they remained within the reference range. Significant decline in hemoglobin values were observed in adult healthy Beagle dogs [26]; and were associated with hemolysis [1].

A significant $(P=0.0453)$ decrease in ALT values was found between $120 \mathrm{POST}$ and $24 \mathrm{hPOST}$ 
in adult dogs, yet the values remained within the reference range. This decrease did not have clinical significance. On the other hand, a study performed in medium sized dogs submitted to long-term WBV showed no significant changes in ALT values [26]. An increase of ALT values in human patients undergoing short-term WBV were associated with elevated room temperature, high altitude, and exercise intensity [15]. Creatinine values decreased significantly $(P=0.0173) 24 \mathrm{~h}$ after the WBV session in adult dogs, also the values remained within the reference values. Such decline was considered not normal since CREAT is a product derived from the metabolism of creatine, and an increase of these parameters in healthy dogs after undergoing physical training was associated with increased muscle catabolism [23].

The hemogasometric parameters showed no significant alterations and was corroborated with the study with healthy horses at frequencies between 15 and $21 \mathrm{~Hz}$ for $10 \mathrm{~min}$ [4]. The limitation of this study was the small number of dogs which enabled a robust conclusion to be drawn. This fact was associated with a rigid inclusion criterion of the study. The subjects of the adult and elderly groups served as their own controls, and after the WBV sessions the dogs were compared to its own baseline.

\section{CONCLUSION}

Single session of WBV by using a vibrating platform that delivered a vortex wave circulation, at 30 and $50 \mathrm{~Hz}$ frequencies for $5 \mathrm{~min}$ does not induce significant changes in hematobiochemical and hemagasometric parameters in adult and elderly healthy dogs.

\section{MANUFACTURERS}

${ }^{1}$ TheraPlate Revolution. Weatherford, TX, U.S.A.

${ }^{2}$ Becton Dickinson Indústrias Cirúrgicas Ltda. São Paulo, SP, Brazil.

${ }^{3}$ Descarpack Descartaveis do Brasil Ltda. São Paulo, SP, Brazil.

${ }^{4}$ Labtest Diagnóstica S.A. Lagoa Santa, MG, Brazil.

${ }^{5}$ Nova Analítica Importação e Exportação Ltda. São Paulo, SP, Brazil.

${ }^{6}$ Laborlab Laboratório de Análises Bioquímicas Ltda. Guarulhos, SP, Brazil.

${ }^{7}$ Siemens Healthcare Diagnósticos S.A. Rio de Janeiro, RJ, Brazil.

${ }^{8}$ DataCamp Inc. Philadelphia, PN, USA.

Acknowledgements. The authors want to thank the Coordination for the Improvement of Higher Education Personnel (CAPES) Brazil, for financial support - Finance Code 1778083/2017.

Ethical approval. This experiment was approved and performed under the guidelines of the Ethics Committee in Animal Experimentation of the Faculty of Veterinary Medicine and Animal Science (FMVZ) of UNESP - São Paulo State University, Botucatu, São Paulo, under protocol no 0133/2017.

Declaration of interest. The authors report no conflicts of interest. The authors alone are responsible for the content and writing of the paper.

\section{REFERENCES}

1 Ando H., Nieminen K., Toppila E., Starck J. \& Ishitake T. 2005. Effect of impulse vibration on red blood cells in vitro. Scandinavian Journal of Work, Environment and Health. 31(4): 286-290. DOI: 10.5271/sjweh.884.

2 Cardinale M. \& Bosco C. 2003. The use of vibration as an exercise intervention. Exercise and Sport Sciences Review. 31(1): 3-7. PMID: 12562163.

3 Cardinale M. \& Wakeling J. 2005. Whole-body vibration exercise: are vibrations good for you? British Journal of Sports Medicine. 39(9): 585-589. DOI: 10.1136/bjsm.2005.016857.

4 Carstanjen B., Balali M., Gajewski Z., Furmanczyk K., Bondzio A., Remy B. \& Hartmann H. 2013. Short-term Whole-body vibration exercise in adult healthy horses. Polish Journal of Veterinary Sciences. 16(2): 403-405. DOI: 10.2478/pjvs-2013-0057.

5 Carstanjen B., Pennecke J., Boehart S. \& Müller K.E. 2010. Unilateral polydactylism in a German Holstein-Friesian calf-A case report. Thai Journal of Veterinary Medicine. 40(1): 69-74.

6 Cochrane D.J. 2011. Vibration exercise: the potential benefits. International Journal of Sports Medicine. 32(2): 75-99. PMID: 21165804.

7 Crewther B., Cronin J. \& Keogh J. 2004. Gravitational forces and Whole-body vibration: implications for prescription of vibratory stimulation. Physical Therapy in Sport. 5(1): 37-43. DOI: 10.1016/j.ptsp.2003.11.004.

8 Cronin J.B., Oliver M. \& McNair P.J. 2004. Muscle stiffness and injury effects of Whole-body vibration. Physical Therapy in Sport. 5(2): 68-74. PMID: 28950401.

9 Delecluse C., Roelants M. \& Verschueren S. 2003. Strength increase after Whole-body vibration compared with resistance training. Medicine Science Sport Exercise. 35(6): 1033-1041. PMID: 12783053. 
10 Franchignoni F., Vercelli S. \& Özçakar L. 2013. Hematuria in a runner after treatment with whole body vibration: a case report. Scandinavian Journal of Medicine and Science in Sports. 23(3):383-385. DOI: 10.1111/j.16000838.2012.01478.x.

11 Freire L., Rahal S.C., Santos I.F.C., Teixeira C.R., Inamassu L.R. \& Mamprim M.J. 2015. Renal resistive index of adult healthy dogs submitted to short-term Whole-body vibration exercise. Asian Journal of Animal and Veterinary Advances. 10(11): 797-802. DOI: 10.3923/ajava.2015.797.802.

12 Gomes M.V.F., Santos I.F.C., Rahal S.C. \& Silva B.M. 2018. Applicability of Whole-Body Vibration Exercises as a new tool in Veterinary Medicine. Brazilian Journal of Health Biomedicine Science. 17(1): 34-38.

13 Halsberghe B.T. 2017. Long-term and immediate effects of whole body vibration on chronic lameness in the horse: a pilot study. Journal of Equine Veterinary Science. 48: 121-128. DOI: 10.1016/j.jevs.2015.12.007.

14 Jordan M.J., Norris S.R., Smith D.J. \& Herzog W. 2005. Vibration training: an overview of the area, training consequences, and future considerations. Journal of Strength and Conditioning Research. 19(2): 459-466. DOI: 10.1519/13293.1.

15 Kim H.J., Lee Y.H. \& Kim C.K. 2007. Biomarkers of muscle and cartilage damage and inflammation during a 200 km run. European Journal of Applied Physiology. 99(4): 443-447. DOI: 10.1007/s00421-006-0362-y.

16 Laflamme D. 1997. Development and validation of a body condition score system for cats: a clinical tool. Feline Practice. 6: 102-109.

17 Marín P.J. \& Rhea M.R. 2010. Effects of vibration training on muscle strength: a meta-analysis. Journal of Strength and Conditioning Research. 24(3): 871-878. PMID: 20072044.

18 Monteleone G., De Lorenzo A., Sgroi M. \& Di Renzo L. 2007. Contraindications for whole body vibration training: a case of nephrolitiasis. Journal of Sport Medicine and Physical Fitness. 47(4): 443-445. PMID: 18091685.

19 Park S.Y., Son W.M. \& Kwon O.S. 2015. Effects of whole body vibration training on body composition, skeletal muscle strength, and cardiovascular health. Journal of Exercise and Rehabilitation. 11(6): 289-295. DOI: 10.12965/jer.150254.

20 Prisby R.D., Lafage-Proust M.H., Malaval L., Belli A. \& Vico L. 2008. Effects of whole body vibration on the skeleton and other organ systems in man and animal models: what we know and what we need to know. Ageing Research Reviews. 7(4): 319-329. DOI: 10.1016/j.arr.2008.07.004.

21 Rauch F., Sievanen H., Boonen S., Cardinale M., Degens H., Felsenberg D., Roth J., Schoenau E., Verschueren S. \& Rittweger J. 2010. Reporting Whole-body vibration intervention studies: recommendations of the international society of musculoskeletal and neuronal interactions. Journal of Musculoskeletal \& Neuronal Interactions. 10(3): 193-198. PMID: 20811143.

22 Rittweger J., Schiessl H. \& Felsenberg D. 2001. Oxygen uptake during Whole-body vibration exercise: comparison with squatting as a slow voluntary movement. European Journal Of Applied Physiology. 86(2): 169-173. DOI: 10.1007/ s004210100511.

23 Rovira S., Munoz A. \& Benito M. 2008. Effect of exercise on physiological, blood and endocrine parameters in search and rescue-trained dogs. Veterinary Medicine. 53(6): 333-346. DOI: 10.17221/1860-VETMED.

24 Rubin C., Recker R., Cullen D, Ryaby J., McCabe J. \& McLeod K. 2004. Prevention of postmenopausal bone loss by a low-magnitude, high-frequency mechanical stimuli: a clinical trial assessing compliance, efficacy, and safety. Journal of Bone and Mineral Research. 19(3): 343-351. DOI: 10.1359/JBMR.0301251.

25 Santos I.F.C., Rahal S.C., Freire L., Teixeira C.R., Inamassu L.R., Mamprim M.J., Gomes M.V.F. \& Tannus F.C.I. 2017. Acute effect of Whole-body vibration in a female dog with metritis. Acta Scientiae Veterinariae. 45(1): e185. DOI: 456/1679-9216.85344.

26 Santos I.F.C., Rahal S.C., Shimono J., Tsunemi M., Takahira R. \& Teixeira C.R. 2017. Whole-body vibration exercise on hematology and serum biochemistry in healthy dogs. Topics in Companion Animal Medicine. 32(2): 86-90. DOI: 10.1053/j.tcam.2017.07.006.

27 Santos I.F.C., Rahal S.C., Santos A., Inamassu L., Rodrigues M., Tsunemi M., Mamprim M., Rodrigues C., Teixeira C. \& Sato T. 2019. Whole-body vibration on leg muscles thermography and femoral resistive index of in adult healthy dogs. Research in Veterinary Science. 122: 118-123. DOI: 10.1016/j.rvsc.2018.11.003.

28 Torvinen S., Kannus P., Sievänen H., Järvinen T.A.H, Pasanen M., Kontulainen S., Nenonen A., Järvinen T.L.N., Paakkala T., Järvinen M. \& Vuori I. 2003. Effect of 8-month vertical whole body vibration on bone, muscle performance, and body balance: a randomized controlled study. Journal of Bone and Mineral Research. 18(5): 876-884. DOI: $10.1359 / \mathrm{jbmr} .2003 .18 .5 .876$. 
B.M. Silva, I.F.C. Santos, S.C. Rahal, et al. 2020. Effects of Whole-Body Vibration in Hematobiochemical and Hemogasometric Parameters in Adult and Elderly Healthy Dogs. Acta Scientiae Veterinariae. 48: 1777.

29 Verschueren S.M.P., Roelants M., Delecluse C., Swinnen S., Vanderschueren D. \& Boonen S. 2004. Effect of 6-month whole body vibration training on hip density, muscle strength, and postural control in postmenopausal women: a randomized controlled pilot study. Journal of Bone and Mineral Research. 19(3): 352-359. DOI: 10.1359/ JBMR.0301245.

30 Vilar J.M., Rubio M., Carrillo J.M., Domínguez A.M., Mitat A. \& Batista M. 2016. Biomechanic characteristics of gait of four breeds of dogs with different conformations at walk on a treadmill. Journal of Applied Animal Research. 44(1): 252-257. DOI: 10.1080/09712119.2015.1031778. 